\title{
Bovine abortion associated with Staphylococcus aureus infection - characterization of $S$. aureus strain isolated from fetal tissues
}

\author{
Luan Cleber Henker ${ }^{*}$ (D) Marina Paula Lorenzett ${ }^{1}$ (D) Camila Imperico Riboldi ${ }^{2}$ (D) \\ Franciele Maboni Siqueira ${ }^{2}$ (D) David Driemeier ${ }^{1}$ (D) Saulo Petinatti Pavarini ${ }^{1}$ (iD
}

${ }^{1}$ Setor de Patologia Veterinária, Faculdade de Veterinária, Universidade Federal do Rio Grande do Sul (UFRGS), 91540-000, Porto Alegre, RS, Brasil. E-mail: luanchenker@gmail.com. "Corresponding author.

${ }^{2}$ Laboratório de Bacteriologia Veterinária, Faculdade de Veterinária, Universidade Federal do Rio Grande do Sul (UFRGS), Porto Alegre, RS, Brasil.

ABSTRACT: Staphylococcus aureus is a gram-positive bacterium, commonly found colonizing the skin and mucous membranes of humans and animals. This report describes a case of fetal loss associated with $S$. aureus infection in a cow. A six-month old, crossbred male bovine fetus from a beef farm was submitted for necropsy. At gross examination fibrinous pleuropneumonia was observed. Histologically, lesions were restricted to the lungs and consisted of marked multifocal to coalescing areas of inflammatory infiltrate of neutrophils, abundant fibrin exudation, necrosis of bronchiolar epithelium and numerous aggregates of coccoid bacteria. Lung and abomasal fuid bacterial culture yielded pure culture of S. aureus, which was characterized as a multidrug resistant strain. Molecular analysis indicated that the studied strain presented several genes of virulence factors including toxic shock syndrome toxin-1 (tst), staphylococcal enterotoxin type A (sea), PantonValentine leukocidin (pvl), alpha-hemolysin (hla) and delta-hemolysin (hld). This report documents an infrequent case of fetal loss in cattle due to infection with a highly virulent $S$. aureus strain.

Key words: fetal loss, reproduction, cattle, bacteria, virulence genes.

Aborto bovino associado à infecção por Staphylococcus aureus - caracterização da cepa de $S$. aureus isolada a partir de tecidos fetais

\begin{abstract}
RESUMO: Staphylococcus aureus é uma bactéria gram-positiva, comumente encontrada colonizando a pele e as membranas mucosas de humanos e animais. O presente relato descreve um caso de aborto bovino associado à infecção por $S$. aureus. Um feto bovino, macho, cruzado, com seis meses de idade gestacional proveniente de uma fazenda de gado de corte foi submetido para a necropsia. Pleuropneumonia supurativa foi observada na avaliação macroscópica. Histologicamente as lesões encontravam-se restritas aos pulmões e eram representadas por infiltrado inflamatório acentuado, multifocal a coalescente de neutrófilos, acentuada exsudação de fibrina, necrose do epitélio bronquiolar e numerosos agregados bacterianos cocoides. A cultura bacteriana de fragmento de pulmão e líquido do abomaso revelou o crescimento puro de $S$. aureus, que foi caracterizado como uma cepa multirresistente a drogas. Análises moleculares indicaram que a cepa estudada apresentava vários fatores de virulência, incluindo toxina 1 da síndrome do choque tóxico (TSST-1), enterotoxina estafilocócica tipo A (sea), leucocidina Panton-Valentine ( $p v l$ ), hemolisina alfa (hla) e hemolisina delta (hld). O presente relato documenta um caso infrequente de aborto bovino devido à infecção por uma cepa altamente virulenta de $S$. aureus.

Palavras-chave: perda fetal, reprodução, bovinos, bactérias, genes de virulência.
\end{abstract}

Staphylococcus aureus is a gram-positive, catalase-positive bacterium which is commonly reported colonizing the skin, mucous membranes and other sites of healthy carriers, and may be associated with a wide range of clinical conditions in animals and humans (WERTHEIM et al., 2005; PETON \& LOIR, 2014). S. aureus may carry numerous genes encoding virulence factors, which have been associated to its capacity to evade host immune response and ultimately cause disease (FOSTER, 2005). In cattle, such bacterium is commonly associated with cases of chronic mastitis, leading to significant economic losses in the dairy industry (RAINARD et al., 2018).

Abortion in cattle due to $S$. aureus has been infrequently described, and such event is classified as a sporadic cause of fetal loss in the bovine species 
(CORBELLINI et al., 2006). Thorough pathological descriptions of $S$. aureus-induced abortions are scarce. Additionally, data characterizing the virulence factors of $S$. aureus involved in these cases are exceedingly limited. Therefore, the objective of this work was to describe the gross, histopathological, microbiological and molecular findings of a case of bovine abortion associated with a highly virulent $S$. aureus strain.

In August 2018, a crossbred male bovine fetus was referred for postmortem examination at the Setor de Patologia Veterinária, Universidade Federal do Rio Grande do Sul (UFRGS). The fetus was referred from a cow-calf operation beef farm, in the state of Paraná, southern Brazil. Herd was composed of 2,500 cows raised in grassland, and only sporadic abortions had been previously documented. The aborting animal was a 6-year-old, multiparous Zebu cow (forth calving), with no history of health problems or treatments, which did not show any clinical signs before or after abortion. In the referred farm, vaccination against the main reproductive pathogens used to be routinely conducted, including Bovine herpesvirus type I, Bovine Viral Diarrhea Virus and Leptospira spp., and the herd overall health status was good. Reproductive management used to be performed with artificial insemination, and natural service was only used in empty cows.

Fetus crown-rump length measured $57 \mathrm{~cm}$, compatible with six months of gestation. External examination revealed no abnormalities. Fetal membranes were not available for evaluation. At the necropsy, gross lesions were restricted to the lungs and were characterized by moderate fibrin deposition covering the visceral pleura surface in the pulmonary cranioventral area (Figure 1A). Samples of various organs were collected and fixed in $10 \%$ formalin. Fixed tissues were routinely processed, embedded in paraffin wax, and sections $(3-4 \mu \mathrm{m})$ were stained by hematoxylin and eosin. In addition, lung sections were stained with Brown-Hopps method.

Histologically, marked multifocal to coalescing areas characterized by inflammatory infiltrate of neutrophils, fewer lymphocytes and macrophages, as well as abundant fibrin exudation, necrosis, accumulation of cell debris and numerous aggregates of $0.5-1 \mu \mathrm{m}$ coccoid bacteria were observed affecting alveolar spaces, bronchioles and bronchi (Figure 1B-C). Also, interlobular septa were markedly expanded by fibrin exudation and edema, and abundant fibrin deposition associated with inflammatory infiltrate of neutrophils was seen covering the visceral pleura. No microscopic lesions were detected in other organs. Brown-Hopps staining showed that bacterial aggregates observed in the lungs were gram-positive cocci (Figure 1D).

Fresh samples were collected aiming to perform microbiological diagnostic tests. Lung fragments and abomasal fluid were inoculated on 5\% sheep blood agar and MacConkey agar and incubated at $37{ }^{\circ} \mathrm{C}$ for $72 \mathrm{~h}$ in aerobic and microaerophilic atmosphere. The isolated bacterium was identified by MALDI-TOF mass spectrometry (MS), using Microflex LT instrument and MALDI Biotyper 3.1 software (Bruker Daltonik, Bremen, Germany), and antimicrobial susceptibility test was performed using Kirby-Bauer method accordingly to the Clinical and Laboratory Standard Institute guidelines (CLSI, 2018). Methicillin resistance was verified by conventional PCR for mecA gene and by the KirbyBauer method using cefoxitin and oxacilin.

Pure white, bright, hemolytic, medium size colonies grew in the blood agar in aerobic and microaerophilic conditions, in both inoculated samples, while no growth was observed from MacConkey agar. The isolated bacterium was classified as a catalase and coagulase positive grampositive coccus, which was identified by MALDITOF as $S$. aureus. This bacterium showed resistant phenotype to tetracycline, gentamicin, ceftazidime, ciprofloxacin, erythromycin, and chloramphenicol, characterizing the isolate as a multidrug resistant (MDR) bacterium. Otherwise, the strain was susceptible to sulfamethoxazole+trimethoprim, penicillin, imipenem and amoxicillin. Besides that, the $S$. aureus showed intermediary susceptibility to oxacillin and cefoxitin. However, the strain was negative to $m e c A$ gene.

Genomic DNA from the isolated bacterium was extracted and a molecular characterization was conducted by PCR assays to search the following virulence marker genes: toxic shock syndrome toxin-1 (tst), staphylococcal enterotoxin type A (sea), Panton-Valentine leukocidin $(p v l)$, alpha-hemolysin ( $h l a$ ) and delta-hemolysin ( $h l d)$, as previously described (ROSSATO et al., 2018). All the referred virulence marker PCR assays yielded positive results, providing information to assume the highly virulent character of the $S$. aureus studied. In addition, fresh kidney and liver samples were tested for Leptospira spp. through PCR as previously described (AHMED et al., 2012), and thymus and spleen samples were tested for pestivirus (BVDV) (VILCEK et al., 1994), both of which yielded negative results.

Abortion is considered a significant cause of economic losses in livestock systems worldwide and frequently represents a diagnostic challenge 


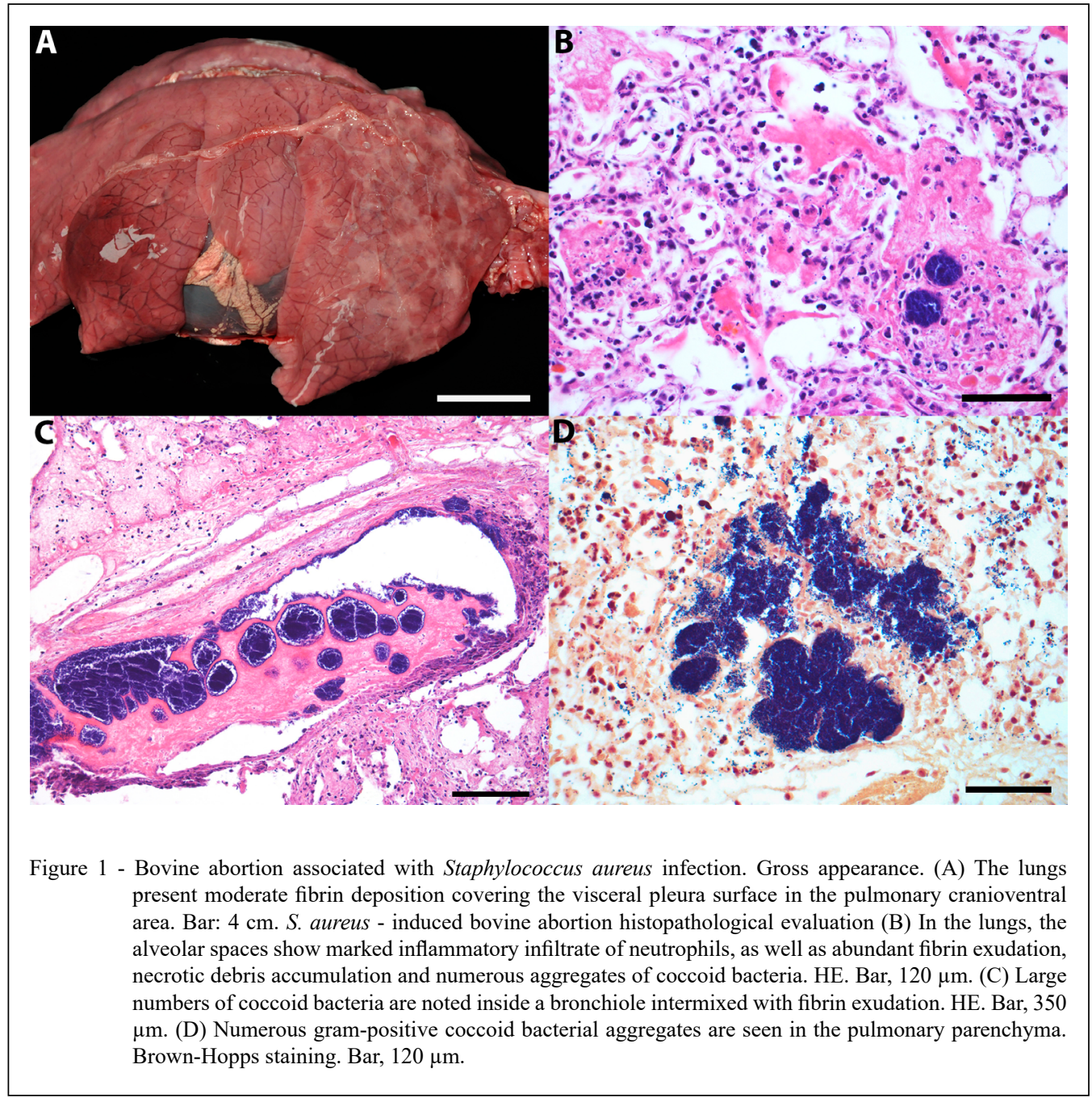

(CABELL, 2007). The main differential diagnosis in the present case should include other causes of pleuropneumonia and bronchopneumonia in bovine aborted fetuses, mainly $B$. abortus infection (POESTER et al., 2013), as well as sporadic bacterial agents (ANDERSON et al., 1990). However, based on histological and microbiological examinations, the aforementioned agents may be easily differentiated. Species in the genus Staphylococcus that have been implicated with abortion in cattle include Staphylococcus lugdunensis (ARDIGÒ et al., 2014) and $S$. aureus (CLOTHIER \& ANDERSON, 2016). $S$. aureus infection has been associated mainly with bronchopneumonia, and rarely with skin lesions in bovine fetuses (CORBELLINI et al., 2006).

In the present case, the lungs were the only affected organs, and large numbers of coccoid aggregates were seen inside bronchioles and bronchi, which may be associated with inhalation of bacteria present in the amniotic fluid (MILLER, 1977). Bacterial infections leading to abortion may be a result of systemic bacterial spread, as well as reproductive tract ascending infections (PARTHIBAN et al., 2015). In the present case, however, it was not possible to infer the route of fetal infection, since no previous disease that could justify fetal spread was detected in the aborting dam.

$S$. aureus isolated was a methicillin sensitive strain (MSSA), but resistant to several antibiotics. S. aureus may express several virulence factors which have been associated with adhesion to host cells, tissue invasion and damage, host immune system escape, disease promotion, cytokine production, and systemic inflammation (FOSTER, 
2005). Although well characterized and described in human isolates, to the best of our knowledge, no information regarding virulence factors present in animal abortion associated-S. aureus strains is currently available. The identified genes from the $S$. aureus here described encoding toxins, tst, sea, $p v l$, $h l a$ and $h l d$, have been described as some of the most frequent virulence genes of $S$. aureus (ROSSATO et al., 2018). The expression of these virulence factors is coordinated by cell-communication system (quorumsensing) in response to population density (KONG et al., 2016).

In conclusion, $S$. aureus should be considered as a sporadic cause of bacterial abortion in cattle, mainly in fetuses presenting fibrinosuppurative pleuropneumonia and bronchopneumonia. In the present case, the isolate was a multidrug resistant strain which presented several genes of virulence factors, indicating that these may play a role in $S$. aureus-induced abortion in cattle.

\section{ACKNOWLEDGEMENTS}

We would like to thank Laboratório de Cocos Grampositivos from Universidade Federal de Ciências da Saúde de Porto Alegre for providing the primers and positive control samples used in this study. This work was supported by the Conselho Nacional de Desenvolvimento Científico e Tecnológico (CNPq) and Coordenação de Aperfeiçoamento de Pessoal de Nível Superior (CAPES), Brasil - Finance code 001.

\section{BIOETHICS AND BIOSSECURITY COMMITTEE APPROVAL}

We authors of the article entitled "Bovine abortion associated with Staphylococcus aureus infection characterization of associated strain virulence " declared, for all due purposes, the project that gave rise to the present data of the same has not been submitted for evaluation of the Ethics Committee of the Universidade Federal do Rio Grande do Sul (UFRGS), but we are aware of the content of the Brazilian resolutions of the Conselho Nacional de Controle de Experimentação Animal (CONCEA) $<$ http://www.mct.gov.br/ index.php/content/view/310553.html $>$ if it involves animals. Thus, the authors assume full responsibility for the presented data and are available for possible questions, should they be required by the competent authorities.

\section{DECLARATION OF CONFLICT OF INTERESTS}

The authors declare that they have no conflict of interest. The founding sponsors had no role in the design of the study; in the collection, analyses, or interpretation of data; in the writing of the manuscript, and in the decision to publish the results.

\section{AUTHORS' CONTRIBUTIONS}

The authors contributed equally to the manuscript.

\section{REFERENCES}

AHMED, S. A. et al. Rapid diagnosis of Leptospirosis by Multiplex PCR. Malaysian Journal of Medical Sciences, v.19, n.3, p.9-16, 2012. Available from: <https://www.ncbi.nlm.nih.gov/ pubmed/23610544>. Accessed: Mar. 20, 2019.

ANDERSON, M. L. et al. A survey of causes of bovine abortion occurring in the San Joaquin Valley, California. Journal of Veterinary Diagnostic Investigation, v.2, n.4., p.283-287, 1990. Available from: <https://www.ncbi.nlm. nih.gov/pubmed/2095280>. Accessed: Mar. 17, 2019. doi: $10.1177 / 104063879000200405$.

ARDIGÒ, P. et al. Abortion in cattle due to infection with Staphylococcus lugdunensis. Journal of Veterinary Diagnostic Investigation, v.26, n.6, p.818-820, 2014. Available from: <https:// www.ncbi.nlm.nih.gov/pubmed/25292193>. Accessed: Mar. 17, 2019. doi: $10.1177 / 1040638714550182$.

CABELL, E. Bovine abortion: aetiology and investigations. In Practice, v.29, p.455-463, 2007. Available from: <https:// inpractice.bmj.com/content/29/8/455>. Accessed: Mar. 15, 2019.

CLSI. Performance standards for antimicrobial disk and dilution susceptibility tests for bacteria isolated from animals. 4th ed. CLSI supplement VET08. Wayne, PA, 2018. Available from: <https:// clsi.org/standards/products/veterinary-medicine/documents/ vet01/>. Accessed: Mar. 20, 2019.

CLOTHIER, K.; ANDERSON, M. Evaluation of bovine abortion cases and tissue suitability for identification of infectious agents in California diagnostic laboratory cases from 2007 to 2012. Theriogenology, v.85, n.5, p.933-938, 2016. Available from: $<$ https://www.ncbi.nlm.nih.gov/pubmed/26679514>. Accessed: Mar. 15, 2019. doi: 10.1016/j.theriogenology.2015.11.001.

CORBELLINI, L. G. et al. Staphylococcus spp. abortion: skin lesions caused by Staphylococcus aureus infection in an aborted bovine-fetus. Veterinary Research Communications, v.30, v.7, p.717-721, 2006. Available from: <https://www.ncbi.nlm.nih. gov/pubmed/17004036>. Accessed: Mar. 19, 2019. doi: 10.1007/ s11259-006-3353-x

KONG, C. et al. Targeting Staphylococcus aureus toxins: a potential form of anti-virulence therapy. Toxins, v.8, n.3, p.121, 2016. Available from: <https:/www.ncbi.nlm.nih.gov/ pubmed/26999200>. Accessed: Mar. 18, 2019. doi: 10.3390/ toxins 8030072 .

MILLER, R. B. A summary of some of the pathogenetic mechanisms involved in bovine abortion. The Canadian Veterinary Journal, v.18, n.4, p.87-95, 1977. Available from: $<$ https://www.ncbi.nlm.nih.gov/pmc/articles/PMC1697519/>. Accessed: Mar. 16, 2019.

PARTHIBAN, S. et al. Review on Emerging and Reemerging Microbial Causes in Bovine Abortion. International Journal of Nutrition and Food Sciences, v.4, n.4-1, p.1-6, 2015. Available from: $\quad<$ https://pdfs.semanticscholar.org/0fd5/12367346ae9631 025ca7524e55eaf4798cdd.pdf $>$. Accessed: Mar. 18, 2019. doi: 10.11648/j.ijnfs.s.2015040401.11.

PETON, V.; LOIR, Y. L. Staphylococcus aureus in veterinary medicine. Infection, Genetics and Evolution, v.21, p.602615, 2014. Available from: <https://www.ncbi.nlm.nih.gov/ 
pubmed/23974078>. Accessed: Mar. 16, 2019. doi: 10.1016/j. meegid.2013.08.011.

POESTER, F.P. et al. Pathogenesis and pathobiology of brucellosis in livestock. Revue scientifique et technique (International Office of Epizootics), v.32, n.1, p.105-115, 2013. Available from: $<$ https://www.ncbi.nlm.nih.gov/pubmed/23837369>. Accessed: Mar. 18, 2019. doi: 10.20506/rst.32.1.2193.

RAINARD, P. et al. Knowledge gaps and research priorities in Staphylococcus aureus mastitis control. Transboundary Emerging Diseases, v.65, p.149-165, 2018. Available from: $<$ https://www.ncbi.nlm.nih.gov/pubmed/28984427>. Accessed: Mar. 20, 2019. doi: 10.1111/tbed.12698.

ROSSATO, A. M. et al. Coexistence of virulence genes in methicillin-resistant Staphylococcus aureus clinical isolates. Revista da Sociedade Brasileira de Medicina
Tropical, v.51, n.3, p.361-363, 2018. Available from: $<$ http://www.scielo.br/scielo.php?script=sci abstract\&p $\mathrm{id}=\mathrm{S} 003786822018000300361 \& \operatorname{lng}=\mathrm{pt} \& \mathrm{nrm}=\mathrm{iso} \& \mathrm{t} \operatorname{lng}=$ en>. Accessed: Mar. 16, 2019. doi: 10.1590/0037-86820339-2017.

VILCEK, S. et al. Pestiviruses isolated from pigs, cattle and sheep can be allocated into at least three genogroups using polymerase chain reaction and restriction endonuclease analysis. Archives of Virology, v.136, n.3-4, p.309-323, 1994. Available from: <https:// www.ncbi.nlm.nih.gov/pubmed/8031236>. Accessed: Mar. 21, 2019. doi: $10.1007 /$ bf01321060.

WERTHEIM, H. F. L. et al. The role of nasal carriage in Staphylococcus aureus infections. The Lancet Infectious Diseases, v.5, n.12, p.751-762, 2005. Available from: <https:// www.ncbi.nlm.nih.gov/pubmed/16310147>. Accessed: Mar. 17, 2019. doi: 10.1016/S1473-3099(05)70295-4. 